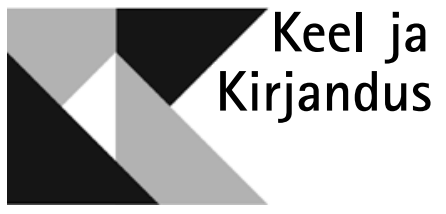

\title{
EESTI VERBI VORMISTIK
}

\author{
HEIKI-JAAN KAALEP
}

\section{Sissejuhatus}

$\mathrm{E}$ i ole niisama lihtne otsustada, kas võimalus ühe sõnavormi grammatilist tähendust mitmel moel tõlgendada on keeles päriselt olemas või on mitmesuse tekitanud grammatikakirjelduse esitaja. Alljärgnevalt vaadeldakse eesti verbi pöördeliste vormide põhiparadigmat, st verbi võimalikke lihtvorme, ning püütakse anda vastus küsimusele, milliseid grammatilisi kategooriaid iga vorm esindab. Seejuures osutatakse ka mõnele kategooriate kombinatsioonile, mida esindavaid verbivorme võib reaalselt kohata, kuid mis on verbiparadigma kirjeldusest pahatihti välja jäänud.

Aastal 1992 kirjutas Ülle Viks oma „Väikese vormisõnastiku” grammatikaosas: „Verbivormistiku koosseis ei ole eesti keele kirjeldustes päris kindel. Igas allikas, mis üldse vormistiku ülevaate annab, on see mõnevõrra erinev" (Viks 1992: 28). Sõnastikus ja tema grammatikaosas kasutas Ülle Viks verbivormi tähistamiseks mitmel pool tüvele liituvate tunnusmorfeemide komplekti - morfoloogilise formatiivi - põhivarianti, nt nii kindla kõneviisi mineviku ainsuse 2. pöörde kui ka mitmuse 3. pöörde (elasid) jaoks SID, umbisikulise tegumoe mineviku kesksõna (elatud, vaadeldud) jaoks TUD. Seega jäeti rõhutamata, milliseid grammatilisi kategooriaid verbivorm esitab. Selline otsus kajastab olukorda, kus eri allikad pakuvad samale vormile erinevaid tõlgendusi, nt elagu on käskiva või möönva või mõlema kõneviisi vorm. Nimetades antud vormi GU-vormiks, saab keskenduda sellele, kuidas vormi moodustatakse, 
jättes seejuures kõrvale vormi nimetamise ja tõlgendamisega seotud probleemid kui antud juhul mitteolulised.

Ülle Viksi tööd, sh „Väike vormisõnastik”, on enamiku eesti keele automaatse morfoloogilise töötlemise arvutiprogrammide aluseks (sh nende, mida kasutatakse tekstikorpuste automaatseks morfoloogiliseks märgendamiseks). Otsus kasutada verbivormide tähistamiseks grammatiliste kategooriate asemel formatiive (mida nt Filosofti morfoloogiatarkvara on järginud) mõjutab otseselt nii eesti keele alast arvuti- kui ka korpuslingvistilist uurimistööd. Ühel hetkel tuleb paratamatult formatiive tõlgendada, st esitada neid grammatiliste kategooriate kombinatsioonidena. Ehk teiste sõnadega, peab ikkagi otsustama, milline on eesti verbivormistiku koosseis. Käesoleva artikli eesmärk on esitada eesti verbide lihtvormide morfoloogia kirjeldamiseks sobiv grammatiliste kategooriate süsteem ning seda ka põhjendada.

Oma süsteemiga väljatulemise põhjuseks on asjaolu, et ükski olemasolevatest ei rahulda ei järjekindluse ega praktilise rakendatavuse poolest. Eraldi peaks mainima, et viimasel ajal verbivormistikuga kõige rohkem tegelenud autorid lähenevad teemale süntaksi seisukohalt, nt (Erelt 2013b; Metslang, Sepper 2010). Nad pööravad grammatiliste tähenduste käsitlemisel tähelepanu pigem vormide semantilistele tõlgendusvõimalustele ning nende kombineerumisvariantidele mitmesõnalise öeldise moodustamisel, mitte aga sellele, mida üksik verbivorm oma paratamatus piiratuses tõepoolest väljendab või ei väljenda. Keele kirjeldamise modulaarsuse põhimõte seevastu nõuab, et kirjeldustasandid tuleks lahus hoida; verbivormistik on kitsam valdkond kui öeldisevormistik, kuigi verbivormistiku adekvaatne mõistmine omakorda aitab paremini käsitleda öeldisevormistikku.

Üks küsimusi, millega artikkel tegeleb, on süstemaatiline mitmesus (mida Ülle Viks (1984) on nimetanud paradigmasiseseks homonüümiaks) ja alaspetsifitseeritus. Süstemaatilise mitmesuse näiteks on nähtus, et ainsuse 2. pööret ja mitmuse 3. pööret esindab mitmes kõneviisis sama vorm: sa/nad elasid; sa/nad elaksid. Ja esineb ka vorme, mida võib lauses kasutada koos mis tahes isiku ja arvuga, nt $\mathrm{ma} / \mathrm{sa} / \mathrm{ta} / \mathrm{me} / \mathrm{te} / \mathrm{nad}$ elaks. Kas viimasel juhul tuleks öelda, et vormil on kuus tõlgendusvõimalust, või tuleks öelda, et vorm on alaspetsifitseeritud, ei väljendagi ei isikut ega arvu ja tal on seega ainult üks tõlgendusvõimalus?

Artiklis ei kasutata paralleelvormi mõistet, sest lihtvormidega piirduvas käsitluses puudub selle järele vajadus. Kui paralleelvormide all mõeldakse erikujulisi, kuid grammatilise tähenduse poolest täiesti võrdseid verbivorme, nagu mõtelnud = mõelnud, siis grammatiliste kategooriate süsteemi seisukohalt ei ole nende olemasolu või puudumine oluline. Kui paralleelvormide all mõeldakse aga verbivorme, mida alles teatud konteksti lisamisel võiks tõlgendada grammatiliselt samaväärsetena, nt läheksin ja ( $m a$ ) läheks, siis selline üksiksõnast suurema üksuse vaatlemine jääb väljapoole antud artikli temaatikat.

\section{Esituse mõju tajule}

On vana tõde, et faktide esitamise viisiga võib mõjutada inimese arvamust neistsamadest faktidest. Ühe asjaolu esiletõstmine varjutab teisi ja seda on hea kasutada nii kodu- kui ka mainekujunduses. Keeleuurijad on inimesed 
ja nendegi arusaamist uuritavast objektist mõjutab viis, kuidas seda objekti neile esitatakse.

Eesti verbi morfoloogilised kategooriad on tegumood, aeg, kõneviis, pööre (hõlmab isikut ja arvu) ja kõne(liik). Omavahel kombineerudes annavad nad üsna keeruka vormistiku, mida grammatikates kajastatakse mitmesuguste tabelitena. Tabeli rea või veeru nimeks/pealkirjaks on tavaliselt mõni kategooria (nt aeg, tegumood), võib-olla seejuures koos väärtusega (nt pl 1, personaal) ja tabeli lahtrites neid kategooriaid väljendavad verbivormid (või formatiivid). Võrdluseks on allpool Ülle Viksi (1992: 30) ja Mati Erelti (2013b: 129) tingiva kõneviisi vormistiku tabeliosa.

T a bel 1 .

Tingiva kõneviisi oleviku jaatava kõne formatiivid*

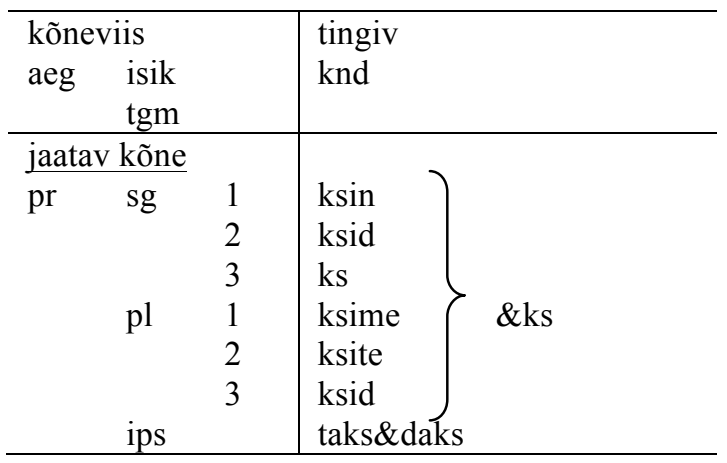

*Viks 1992: 30 .

Tabel 2 .

Tingiva kõneviisi vormistik*

\begin{tabular}{l|l|l}
\hline & personaal & impersonaal \\
\cline { 2 - 3 } jaatav & jaatav \\
\hline preesens & ma teeks(in) & tehtaks \\
sa teeks(id) & \\
ta teeks & me teeks(ime) \\
te teeks(ite) & \\
nad teeks(id) & \\
\hline
\end{tabular}

* Erelt 2013b: 129 . 
Mis tahes kujul, eriti tabeli kujul esitatud andmeid tõlgendades tuleks olla teadlik asjaolust, et esitusviis mõjutab meie arusaamist asjadest. Tabeli puhul on tähtis, et (esitusviisi loogikast lähtudes) ükspäinis rea või veeru pealkirja olemasolu suunab lahtri sisu tõlgendama kui pealkirjas antu realisatsiooni, varianti. Ülaltoodud tingiva kõneviisi tabelite puhul on oluline märgata, et hoolimata vormilistest erinevustest on esitatud formatiivivariandid (või sõnavormid) paigutatud 6 pöörde esinemisvormide lahtritesse.

Ülaltoodud tabelite sisu võiks esitada ka sel moel, et kirjutame otse välja kõik kategooriate väärtused, mida sõnavorm esitab.

T a bel 3 .

\section{Verbivormi kõik kategooriate väärtused}

\begin{tabular}{l|l}
\hline isikuline tgm, olevik, tingiv kv, sg 1, jaatav kõne & teeksin \\
\hline isikuline tgm, olevik, tingiv kv, sg 2, jaatav kõne & teeksid \\
\hline isikuline tgm, olevik, tingiv kv, (sg 1, 2, 3, pl 1, 2, 3), jaatav kõne & teeks \\
\hline isikuline tgm, olevik, tingiv kv, pl 1, jaatav kõne & teeksime \\
\hline isikuline tgm, olevik, tingiv kv, pl 2, jaatav kõne & teeksite \\
\hline isikuline tgm, olevik, tingiv kv, pl 3, jaatav kõne & teeksid \\
\hline umbisikuline tgm, olevik, tingiv kv, jaatav kõne & tehtaks \\
\hline
\end{tabular}

Kui vorm võib esindada ühe kategooria mitut erinevat väärtust, siis saab neid esitada koos, sulgude sees. Kui sulgudes on esindatud ühe kategooria kõik võimalikud väärtused, siis seda võib tõlgendada ka nii, et kategooria on selle vormi puhul määramata, st tema kohta sõnavormis endas info puudub. Antud juhul hakkab silma, et vorm teeks ongi selline, mis ei võimalda määrata ei arvu ega isikut, st ta on nende suhtes alaspetsifitseeritud.

Sisu poolest on viimase tabeli esitatu täpselt sama mis eelnevates, kuid teistsugune esitusviis võimaldab märgata, et mitte kõik esitatud vormid ei ole pöördekategooria suhtes ühetaolised. Tõlgendusvõimalus, et ks (teeks) on pöörde suhtes üldse määratlemata, st ei spetsifitseeri pööret, oli traditsioonilistest tabeli kujul esitatud tõlgendustest välistatud (kui järgida esitusviisi loogikat) iga vorm asetses lahtris, millele oli ette määratud konkreetse isiku ja arvu väärtus.

Varasem keelefaktide (antud juhul verbivormide) esitamise viis tekitas ootused selle suhtes, kuidas neid fakte peaks tõlgendama - antud juhul kõiki kui pöördekategooriat omavatena.

Kategooriaid puudutava terminikasutuse kohta tuleb märkida järgmist.

Paradigmas väljendatavate grammatiliste kategooriate all mõistame neid ja ainult neid, mis on sõnavormi enese piires väljendatud (ega tulene mõnest teisest sõnast, nt abiverbist või eitussõnast), st morfoloogilisi kategooriaid.

Traditsiooniliselt käsitletakse morfoloogilist kategooriat kui hulka, millel on liikmed, nt „Morfoloogiliseks kategooriaks nimetatakse morfoloogiliste tunnuste kujul vormistuvate üksteist välistavate tähenduste klassi. [---] Üksteist välistavaid tähendusi, mis ühe kategooria siseselt väljenduvad erinevate 
tunnuste abil, nimetatakse selle kategooria liikmeteks. Näiteks ainsuse 1. pööre, mida väljendab tunnus $n$, on üks pöördekategooria liige” (EKK: M45).

Definitsioon, mille kohaselt kategooria on liikmetest koosnev hulk, sobib hästi selleks, et kirjeldada keeles väljendatavaid grammatilisi tähendusi just tunnustest lähtudes. Kui huvi all on aga küsimus, milliseid võimalikke grammatilisi tähendusi üks sõnavorm kannab, siis on mugavam kasutada väljendi „kategooria liige” asemel „kategooria väärtust”: verbivormid, mis väljendavad isikulise tegumoe kindlat kõneviisi, väljendavad ka pöördekategooriat, nt verbivormi elan puhul on selle väärtuseks ainsuse 1. pööre. Vaade on seega kategooriate süsteemi poolt sõnavormide poole: on olemas teatud kategooriad, igal kategoorial on mõned võimalikud väärtused, mida konkreetne sõnavorm võib väljendada või mitte väljendada. „Grammatilise kategooria väärtusega” samatähenduslik on „grammatiline tähendus”.

\section{Käskivast ja möönvast kõneviisist}

EKG ja EKK eristavad verbiparadigmas veel üht kõneviisi lisaks käesolevas artiklis esitatavale neljale - möönvat kõneviisi ehk jussiivi, kuhu kuuluvad ainult GU-lõpulised vormid.

\subsection{Möönva kõneviisi käsitluse areng}

Möönva kõneviisi sissetoomine käskiva kõneviisi mõnede vormide asemele (EKG) või kõrvale (Erelt, Metslang 2004; EKK; Erelt 2013a, 2013b) sai alguse ühest Mati Hindi tähelepanekust: „Juhitagu veel tähelepanu käskiva kõneviisi kolmanda pöörde vormi omapärasele üldistumistendentsile, mida ei ole võimalik ka kirjakeeles enam pidurdada. Kolmanda isiku vorm on kindlalt kasutusel ainsuse esimese isiku (mina) puhul, kuid ta levib mujalegi; vrd. lauseid nagu: „Mina tehku tööd ja sina muudkui passid”; [---] „Meie mingu koju, nemad võivad peole edasi jääda"; [---]. Selle üldistatud vormiga väljendatav käsk on niisama kaudne või veel kaudsem kui kolmanda isiku puhul. Kirjakeele grammatika ei või ignoreerida sellist täiesti asendamatut väljendusvõimalust, mis lisab käskiva kõneviisi vormistikule paralleelse ja täieliku paradigma" (Hint 1969: 335).

Mati Hindi täheldatud tava kasutada GU-lõpulisi vorme ka teiste isikute puhul ei ole siiski midagi uut, vaid sajandite vanune (Erelt 2002; Penjam 2005). Mati Erelt (2002) annab põhjaliku ülevaate varasematest GU-lõpuliste vormide paigutamistest verbi paradigmatabeli lahtritesse. Järgnev on sellest kokkuvõte. Mihkel Veske pakkus 1879 välja, et mõnes pöördes kasutatav GU-lõpuline vorm on omaette kõneviis ja nimetas seda optatiiviks; Karl August Hermann ütles 1884, et GU-lõpuline vorm on kasutatav kõigis isikutes ja nimetas seda soovivaks kõneviisiks (optatiiviks), aga seejuures pidas ta 3 . isiku vormidena GU-lõpulisi ka käskiva kõneviisi vormideks; Aarand Roos oli 1982 seisukohal, et kui GU-lõpuline vorm on 3. isikus (ainsuses või mitmuses), siis on ta optatiiv, kui aga 1. isikus, siis imperatiiv; EKG järgi oli GU-lõpuline vorm võimalik ainult möönvas kõneviisis (jussiivis), kusjuures isiku suhtes mittespetsifitseerituna. Erelt (2002) oli viimasega samal seisukohal, v.a see, et tema arvates olid möönval kõneviisil oleviku paradigmas siiski pöörded olemas, kuigi kõik homonüümsed, ühesuguse GU-lõpulise vormiga. 
Praeguseks on jõutud Karl August Hermanniga sarnasele seisukohale, ainult kõneviisi nimi on optatiivi asemel jussiiv (nime kasutusele võtjaks on TiitRein Viitso (1976)), ja nimelt: GU-lõpuline vorm võib esindada käskiva kõneviisi ainsuse või mitmuse 3. pööret ja olla ühtlasi möönvas kõneviisis kas a) mis tahes pöördes (Erelt, Metslang 2004; Erelt 2013a, 2013b) või b) ilma, et pööre oleks määratud (EKK).

Selles käsitluses ei erista käskiva kõneviisi GU-lõpulisi vorme möönva omadest ükski morfoloogiline tunnus. Ainsaks kriteeriumiks on tähendusvarjund: käsu otsesus või kaudsus, nõudlik või soovituslik iseloom. Lahtiseks jääb küsimus, kas seda kriteeriumi on võimalik kasutada - kas tegelikkuses oleks võimalik vahet teha, millist varjundit mõeldakse, nt kas lause Peeter mingu seenele! on käskivas või möönvas kõneviisis, st kas see on käsk või hoopis soov, üleskutse, nõudmine. Raskusi vahetegemisel tunnistab ka Mati Erelt (2013b: 138).

\subsection{Mis on käskival kõneviisil viga?}

Käskiva ja möönva kõneviisi eristamissoovi üks põhjus näib seisnevat eri vormide kasutamisvõimaluste ebasümmeetrilisuses eri pööretes: kui mina, tema ja nemad puhul saab kasutada ainult ühte vormi (elagu) ja seda ainult nõudmiseks, soovimiseks, siis sina, meie ja teie puhul saab kasutada üht vormi käskimiseks (ela, elage) või üleskutseks (elagem) ja teist nõudmiseks, soovimiseks (elagu).

Protest soovi või üleskutset väljendava GU-lõpulise vormi käsuks liigitamise vastu on mõistetav, kuivõrd eestikeelne termin „käskiv kõneviis” omab tõepoolest antud juhul eksitavat tähendusvarjundit. Samas, ka käskiva kõneviisi mitmuse 1. isiku GEM-lõpuline vorm (elagem), mida keegi möönvasse kõneviisi ei paiguta, ei ole õigupoolest mitte käsk, vaid üleskutse - iseennast ei saa käskida. Sarnasel põhjusel ongi kasutusel mitmuse 1. isiku käsusarnase vormina kindla kõneviisi olevik tuleviku tähenduses (jookseme; eitavana ärme jookse(me)): „käsk meile” ei ole muud kui plaan teha midagi tulevikus (ja tulevikku saab eesti keeles väljendada ainult olevikuvormi kaudu). Seega kui lähtuksime nõudmisest, et käskiva kõneviisi vorm peab väljendama otsest käsku, muidu ta selle kõneviisi vormiks ei kõlba, siis jääks sinna ainult kaks vormi, ainsuse ja mitmuse 2 . isiku omad. Põhjendada mõnede vormide mittesobivust nende mittekäsulikkusega on kõneviisi tähistava termini valiku teema, st nimetamise küsimus, millest ei pruugi tuleneda vormide teistsuguse liigitamise vajadust.

\subsection{Pole isikut - pole probleemi}

Tuleb tunnistada, et käskiva ja möönva kõneviisi eritlemine toob kaasa suuri teoreetilisi ja praktilisi probleeme, seetõttu võiks küsida: võib-olla on GU-lõpuliste vormide paigutamisel verbiparadigmasse võimalik leida mõni alternatiivne lahendus?

Käskiva kõneviisi GU-lõpulise vormi varasemaid käsitlusi näib iseloomustavat arvamus, et sõnavormi lõpus on veel midagi peale kõneviisi tunnuse, nii et näiteks möönva kõneviisi alane käsitlus algab lausega: „Eesti keele üks omapärasid on, et käskiva kõneviisi kolmanda isiku tunnus on laienenud kõigile isikutele, nagu ka umbisikulisele vormile...." (Erelt 2002: 110). Lausest 
paistab, nagu poleks kahtlustki, et verbivorm väljendab mingit isikut, mis sellest, et suvalist. Ka Mati Hint (1969) ei näi kahtlevat, et GU-lõpuline vorm on 3. isiku vorm. See seisukoht, mis pole kaugeltki enesestmõistetav (nimelt et vorm, mida võib kasutada kõigi isikutega, on justnimelt 3. isiku vorm, mitte isikustamata vorm), on võetud argumentatsiooni eelduseks.

Mati Erelti lause eesti keele omapärast võiks sõnastada ka järgmiselt: tunnus gu/ $k u$ on kaotanud võime eristada arvu ja isikut; sama tunnus on ka umbisikulises tegumoes käskiva kõneviisi oleviku verbivormi lõpetavaks tunnuseks. Sellest küljest vaadatuna ei tundugi enam enesestmõistetav, et gu / $k u$ on mingi isiku tunnus; vastupidi, kuna ta on umbisikulise tegumoe verbivormi lõpetavaks tunnuseks, selles tegumoes aga isikut olla ei saa, siis ei saa gu/ku olla ka isiku tunnuseks.

GU-lõpulisel vormil puudub pöördetunnus ja vormi saab kasutada mis tahes isiku ja arvu korral. Seega puudub tal käsu oluline atribuut: isik, kellele käsk antakse, on spetsifitseerimata. On loomulik, et sellisel juhul on vormil ka selge tähendusvarjund - käsulikkust ei ole, selle asemel on soov, nõudmine, üleskutse, et „keegi teeks”. Käskiva kõneviisi vormid erinevad üksteisest oma tähenduse poolest palju rohkem kui muude kõneviiside vormid kõneviisisiseselt. See on tingitud käsu-nõudmise-soovi olemusest, mis on pöördekategooriaga hoopis tugevamalt seotud kui muude kõneviiside tähendused.

Võrdluseks võiks vaadata ka muude kõneviiside vormistikke lootuses, et ehk on eesti verbi vormistik niivõrd sümmeetriline, et teistes kõneviisides ilmnevad mustrid on täheldatavad ka käskivas kõneviisis.

Tõepoolest, tingivas kõneviisis on nii oleviku kui mineviku ks-lõpuline vorm kasutatav kooskõlas isikulise asesõna mis tahes isiku ning arvuga, st vormil puudub isiku ja arvu täpsustamise võime. Samasugust võimetust isikut ja arvu täpsustada näeme kaudses kõneviisis (vat-vormi näol) ning ka käskivas kõneviisis GU-vormi näol. $k s$-lõpulises ning vat-lõpulises vormis on lihtsalt nähtav, et verbivormi lõpetavaks morfoloogiliseks tunnuseks ongi kõneviisi tunnus: ma, sa, ta, ... (ei) ela-ks / ela-vat; ela-nu-ks / ela-nu-vat; umbisikulises tegumoes (ei) ela-ta-ks / ela-ta-vat; ela-t-u-ks / tarvita-ta-nu-vat.

Tabelist 4 on näha, et käskiva kõneviisi oleviku paradigma asub pöördevormide poolest justkui tingiva ja kaudse vahel. Kõigis neis kõneviisides on üks vorm, mis on nii jaatuse-eituse kui ka pöörde osas määramata: elaks, elagu, elavat. Peale selle vormi on aga ka üksikute pöörete osas määratud vorme. Tingivas kõneviisis on määratud viis oleviku paradigma liiget, käskivas kolm ja kaudses mitte ühtegi.

Käskiva kõneviisi vormistik sobitub verbi paradigmasse väga hästi ja pole põhjust seda kaheks jagada, et eristada möönvaid ehk jussiivseid GU-lõpulisi vorme.

Üleskutse lisada veel üks paralleelne ja täielik alamparadigma käskiva kõneviisi kõrvale meenutab ammuseid katseid pidada vokatiivi eesti keele käändeks (klausliga, et vokatiiv langeb alati kokku nominatiiviga), st see paistab olevat lingvisti poolt esitletav eristus keele morfoloogilises süsteemis, millele tegelikku, keelest endast tulenevat põhjendust ei ole leida. 


\section{Finiitsete lihtvormide paradigma}

Tabel 4 esitab verbi finiitsete lihtvormide paradigma, st verbi võimalike vormide hulga; tabel 5 esitab täielikkuse mõttes ka infiniitsed vormid, kuigi käesolev artikkel nende kohta midagi uut ei ütle.

Enne kui hakata uuel moel tervet paradigmat välja kirjutama, tuleks otsustada, millises järjekorras kategooriaid esitada. Seejuures oleks hea, kui järjekorra valik oleks põhjendatud.

Üldiselt on teada, et grammatilised kategooriad, õigemini neid kandvad morfeemid, ei liitu tüvele suvalises järjekorras. Tuletusliide asetseb tüve ja muutevormi moodustamiseks kasutatava tunnusmorfeemi vahel (Greenberg 1990: 57), nimisõnadel asetseb arvukategooriat väljendav tunnus peaaegu alati tüve ja käändekategooriat väljendava tunnuse vahel (Greenberg 1990: 59). Kategooriaid väljendavate tunnuste lähedust tüvele tõlgendab Joan Bybee (1985: 34-35) nende kategooriate olulisuse näitajana, kusjuures ta osutab $\mathrm{ka}$, et paljudes keeltes tavapärane verbi tunnusmorfeemide järjestus tüvest alates (kui vaadata ainult eesti verbis esinevaid kategooriaid) on: tegumood, aeg, kõneviis, arv ja isik (ehk pööre). Neid kategooriaid väljendavad tunnused paiknevad samas järjekorras ka eesti keeles. (Eituse kategooria kohta ei ütle Bybee (1985) midagi.)

Tabeli 4 ülesehitus järgib tunnusmorfeemide sõnasisest järjestust: vasakul pool olev veerg esindab grammatilist kategooriat, mille tunnus on tüvele lähemal, ja parempoolne kategooriat, mille tunnus on tüvest kaugemal. Vormid paigutatakse tabelisse sellises järjekorras nagu ikka, kui tahetakse mitmest muutuvast elemendist (nt täisarvudest) koosnevaid jadasid järjestada: esimeses järjekorras vaheldub ainult kõige viimane element, seejärel eelviimane jne. Selle tulemusena näeb tabel välja nagu (vasakult paremale läbitav) otsustuspuu, kus igas veerus valitakse sel hetkel võimaliku grammatilise kategooria võimalike väärtuste vahel.

On võimalik, et sel otsustuspuul on ka reaalne psühholoogiline sisu, arvestades sõnavormide moodustamise ja kuuldavale toomise protsessi ajalist iseloomu: vasemal olev element eelneb ajaliselt parempoolsele.

Eriolukord on eituse kategooriaga, mis paistab erandlikult olevat osalt sõnavormisiseselt, osalt sõnavormiväliselt määratletav ega sobitu hästi morfoloogiliste tunnuste järjestuspõhimõttega. Üheselt on eituse olemasolu määratud ainult ühes paradigma liikmes - umbisikulise tegumoe kindla kõneviisi olevikus (elata), ehkki isegi see vorm on paljudel sõnadel homonüümne $d a$ infinitiiviga (hüpata) ning lause grammatiline korrektsus nõuab talle eelnevat eitussõna $e i$ või $e g a$. Kõik ülejäänud eitava kõne võimalusega lihtvormid nõuavad eituse realiseerumiseks eitussõna ei, ära või ega olemasolu. Kuna eitussõna eelneb lauses verbivormile, siis teadmine kõnekategooria väärtusest (eitav või jaatav) peaks kõnelejal (ja ka kuulajal) olema juba enne verbi leksikaalse sisu ilmumist, rääkimata muudest grammatilistest kategooriatest.

Tabel 4 kajastab morfoloogilisi kategooriaid nende võimalike väärtuste kombinatsioonide kaudu, nagu nad üksikutes verbivormides on esindatud. Sel moel on paremini näha ka sellised väärtuste kombinatsioonid (õigemini nende puudumine), mida tegelikult üheski verbivormis ei esine. Näiteks tingiva kõneviisi eitava kõne puhul on võimalik, et ühe sõna - pole - vorm (poleksin, pol$n u k s i n$ ) väljendab 1. pööret, kusjuures mitte ühegi teise pöörde tõlgendus pole 
T a bel 4 .

Finiitsed lihtvormid

\begin{tabular}{|c|c|c|c|c|c|c|}
\hline tegumood & aeg & kõneviis & pööre & kõne & näide: elama & näide: pole, ära \\
\hline \multirow[t]{8}{*}{ isikuline } & \multirow[t]{4}{*}{ olevik } & kindel & $\begin{array}{l}\text { sg } 1 \\
\text { sg } 2 \\
\text { sg } 3 \\
\text { pl } 1 \\
\text { pl } 2 \\
\text { pl } 3 \\
\text { määramata }\end{array}$ & $\begin{array}{l}\text { jaatav } \\
\text { jaatav } \\
\text { jaatav } \\
\text { jaatav } \\
\text { jaatav } \\
\text { jaatav } \\
\text { eitav }\end{array}$ & $\begin{array}{l}\text { elan } \\
\text { elad } \\
\text { elab } \\
\text { elame } \\
\text { elate } \\
\text { elavad } \\
\text { (ei) ela (1) }\end{array}$ & pole \\
\hline & & tingiv & $\begin{array}{l}\text { sg } 1 \\
\text { sg } 2 \\
\text { määramata } \\
\text { pl } 1 \\
\text { pl } 2 \\
\text { pl } 3\end{array}$ & $\begin{array}{l}\text { jaatav } \\
\text { jaatav } \\
\text { määramata } \\
\text { jaatav } \\
\text { jaatav } \\
\text { jaatav }\end{array}$ & $\begin{array}{l}\text { elaksin } \\
\text { elaksid (2) } \\
\text { elaks } \\
\text { elaksime } \\
\text { elaksite } \\
\text { elaksid (2) }\end{array}$ & $\begin{array}{l}\text { poleksin } \\
\text { poleksid } \\
\text { poleks } \\
\text { poleksime } \\
\text { poleksite } \\
\text { poleksid }\end{array}$ \\
\hline & & käskiv & $\begin{array}{l}\text { sg } 2 \\
\text { määramata } \\
\text { pl } 1 \\
\text { pl } 2 \\
\end{array}$ & $\begin{array}{l}\text { määramata } \\
\text { määramata } \\
\text { määramata } \\
\text { määramata }\end{array}$ & $\begin{array}{l}\text { ela }(1) \\
\text { elagu } \\
\text { elagem } \\
\text { elage } \\
\end{array}$ & $\begin{array}{l}\text { ära } \\
\text { ärgu } \\
\text { ärgem, ärme } \\
\text { ärge } \\
\end{array}$ \\
\hline & & kaudne & määramata & määramata & elavat & polevat \\
\hline & \multirow[t]{4}{*}{ minevik } & kindel & $\begin{array}{l}\text { sg } 1 \\
\text { sg } 2 \\
\text { sg } 3 \\
\text { pl } 1 \\
\text { pl } 2 \\
\text { pl } 3 \\
\text { määramata }\end{array}$ & $\begin{array}{l}\text { jaatav } \\
\text { jaatav } \\
\text { jaatav } \\
\text { jaatav } \\
\text { jaatav } \\
\text { jaatav } \\
\text { eitav } \\
\end{array}$ & $\begin{array}{l}\text { elasin } \\
\text { elasid (3) } \\
\text { elas } \\
\text { elasime } \\
\text { elasite } \\
\text { elasid (3) } \\
(\text { ei) elanud (4) }\end{array}$ & polnud \\
\hline & & tingiv & $\begin{array}{l}\text { sg } 1 \\
\text { sg } 2 \\
\text { määramata } \\
\text { pl } 1 \\
\text { pl } 2 \\
\text { pl } 3 \\
\end{array}$ & \begin{tabular}{|l} 
jaatav \\
jaatav \\
määramata \\
jaatav \\
jaatav \\
jaatav \\
\end{tabular} & $\begin{array}{l}\text { elanuksin } \\
\text { elanuksid (5) } \\
\text { elanuks } \\
\text { elanuksime } \\
\text { elanuksite } \\
\text { elanuksid (5) }\end{array}$ & \begin{tabular}{|l} 
polnuksin \\
$($ polnuksid $)$ \\
polnuks \\
(polnuksime $)$ \\
(polnuksite) \\
polnuksid \\
\end{tabular} \\
\hline & & käskiv & määramata & määramata & elanud (4) & ärnud \\
\hline & & kaudne & määramata & määramata & elanuvat & polnuvat \\
\hline \multirow[t]{6}{*}{ umbisikuline } & \multirow[t]{4}{*}{ olevik } & kindel & \multirow{8}{*}{ 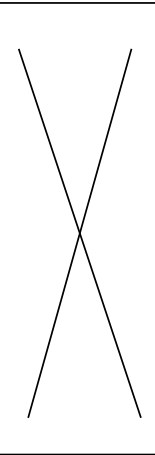 } & $\begin{array}{l}\text { jaatav } \\
\text { eitav }\end{array}$ & $\begin{array}{l}\text { elatakse } \\
\text { elata }\end{array}$ & polda \\
\hline & & tingiv & & määramata & elataks & poldaks \\
\hline & & käskiv & & määramata & elatagu & ärdagu \\
\hline & & kaudne & & määramata & elatavat & poldavat \\
\hline & \multirow[t]{4}{*}{ minevik } & kindel & & $\begin{array}{l}\text { jaatav } \\
\text { eitav }\end{array}$ & $\begin{array}{l}\text { elati } \\
(\text { ei) elatud (6) }\end{array}$ & poldud \\
\hline & & tingiv & & määramata & elatuks & polduks \\
\hline \multirow[t]{2}{*}{-} & & käskiv & & - & - & - \\
\hline & & kaudne & & määramata & tarvitatanuvat & \\
\hline
\end{tabular}


võimalik, kuid kindla kõneviisi puhul pole ühtegi sõna, mille ainus võimalik tõlgendus oleks 1. pööre eitavas kõnes. Vastavad lahtrid on tabelis 4 tühjad.

Vormid (sa) polnuksid, (me) polnuksime ja (te) polnuksite on tabelis sulgudes, sest kuigi nad tunduvad intuitiivselt võimalikud, pole nende kasutamist ei Keeleveebi tekstikorpustest (www.keeleveeb.ee) ega Google'i otsinguga õnnestunud tuvastada.

Hallil taustal on tabelis käskiva kõneviisi mineviku vorm elanud, mille olemasolu ei peeta traditsioonilistes käsitlustes võimalikuks, ning eitussõnad ärnud ja ärdagu, mille vorm on traditsiooniliste käsitluste jaoks ootamatu. Tegelikus keelekasutuses on neid aga kohatud, samuti on neid kirjeldanud Mati Erelt (2013a). Hallil taustal on ka umbisikulise tegumoe kaudse kõneviisi mineviku vorm tarvitatanuvat. Kaudse kõneviisi umbisikulise vormi mineviku tunnuseks pakub (Viks 1992: 30) tuvat/duvat (elatuvat), kuid sellise tunnusega vorme keelekasutusest (mida esindavad Keeleveebi tekstikorpused) ei leia. On õnnestunud leida ainult üks sellist grammatiliste kategooriate komplekti kandev verbivorm, ja selles on mineviku tunnusena kasutusel $n u$ :

Käbi ei kuku kännust kaugele [---] näib tarvitatanuvat eelkõige ikka siis, kui „känd” on mingis mõttes paha ja „käbi” kohta prognoositakse sama.... (Krikmann)

Läbikriipsutusega on üks rida - umbisikulise tegumoe käskiva kõneviisi minevik. See esindab kategooriate väärtuste kombinatsiooni, mis oletatava süsteemi sümmeetrilisuse seisukohalt oleks justkui võimalik, aga et ühtegi sellele kombinatsioonile vastavat verbivormi ei ole õnnestunud leida, tuleb see tunnistada siiski võimatuks.

Mõne näidise lahtris on verbivormi järel sulgudes number. See number on viide, mis hõlbustab homonüümse vormi leidmist samast tabelist, kuivõrd paradigma mõned liikmed on alati homonüümsed mõne teise liikmega, st homonüümia on süstemaatiline ja grammatiline.

Kui mõne kategooria lahtris on „määramata”, siis see tähendab seda, et verbivormi saab antud kategooria mis tahes väärtuse kandjana kasutada, aga verbivorm ise ei määratle ühtegi väärtust. Näiteks elage on jaatuse-eituse osas määramata: üksikuna väljendab see käsku, koos eitussõnaga ära (ärge elage) aga tähendab keeldu, st kannab eitavat tähendust. Seevastu elan on jaatuse osas määratud ja seda ei saa kuidagi kasutada eituses. Elaks ei määra ei pööret ega jaatust-eitust, sobides kasutamiseks koos mis tahes pööret väljendava isikulise asesõnaga, ja seda nii jaatuses kui ka eituses, ilma et tekiks ühildumiskonflikt: ma elaks, ma ei elaks jne, st ta ei välista ühtegi 2 x $6=12$-st võimalusest. Elaksin seevastu kitsendab kasutusvõimalusi maksimaalselt, jättes neist alles ainult ühe: ainsuse 1. isik jaatavas kõnes.

Võib tunduda, et määramatus pole midagi muud kui grammatiline homonüümia, mis lihtsalt hõlmab ühe kategooria kõiki võimalikke väärtusi kandvaid sõnavorme. Tegelikult just siin ongi oluline tähele panna, et erinevalt määramatusest haarab homonüümia sõnavorme, mis on paigutatud (kategooriate süsteemi kohaselt) tabelisse justkui juhuslikult, hoolimata sellest, kas homonüümsete vormide grammatilised tähendused on lähedased või mitte. Näiteks vormide sa elasid ja nad elasid tähendused ei ole omavahel kuidagi sarnasemad kui muud isikulise tegumoe kindla kõneviisi mineviku pöörete tähendused. 
Kategooria määramatusest erineb olukord, kus kategooria ise on sõnavormist üldse puudu. Näiteks umbisikuline tegumood (mida tähistavaks tunnuseks on $t(a)$ ) välistab pöördekategooria, st isiku ja arvu olemasolu võimaluse samas verbivormis. Kui isiku ja arvu määramatuse korral (nt elaks) kõlbab sõnavorm ühilduma mis tahes isikulise asesõnaga, siis isiku ja arvu puudumise korral ei kõlba sõnavorm ühilduma mitte ühegagi neist (nt * $m a, s a, \ldots$ elatakse).

Verbi olema eitava kõne vormid (pole jt) ning eitussõna ära on tabelis toodud esiteks sellepärast, et võimalike kategooriate ja nende väärtuste komplektide ülevaade oleks täielik, st et kõik kombinatsioonid, mis on mingi verbivormi kaudu esindatud, oleksid ka tabelis esindatud. Teiseks on eitust väljendavatel verbivormidel diagnostiline väärtus. Eitus on statistiliselt haruldasem kui jaatus ja see kajastub ka morfoloogilise süsteemi ülesehituses - tabelist paneme tähele, et mitte igale kategooriate väärtuste komplektile, millele vastav verbivorm väljendab lisaks ka jaatust, ei leidu vastavat verbivormi, mis väljendaks jaatuse asemel eitust. Näiteks on olemas verbivorm, mis väljendab isikulise tegumoe oleviku kindla kõneviisi 1. pööret jaatavas kõnes (nt elan), kuid pole vastavat esimese pöörde vormi, mis oleks eitavas kõnes; eitavas kõnes vormidel (nt (ei) ela, pole) on pöördekategooria määratlemata, st nad on vähem spetsifitseeritud, nende poolt väljendatavate kategooriate hulk on väiksem (pöördekategooria võrra). Eitava kõne vormide diagnostiline väärtus seisneb selles, et kui leidub verbivorm, mis väljendab mingit hulka morfoloogiliste kategooriate väärtusi pluss eitust, siis peab tingimata leiduma ka vastav jaatust väljendav verbivorm, mis on ülejäänud kategooriate osas vähemalt samavõrd spetsifitseeritud.

Kuna leidub isikulise tegumoe mineviku käskiva kõneviisi eitav vorm ärnud, siis peavad tegelikus keelekasutuses (ja keelesüsteemis, mida kasutajad ju järgivad) leiduma ka isikulise tegumoe mineviku käskiva kõneviisi jaatavad vormid. Selliste vormide olemasolu eesti keeles on tõepoolest ka teada; hiljuti on sellele tähelepanu juhtinud Mati Erelt (2013a), viidates omakorda varasematele kirjeldustele (Saareste 1952; Sivers 1969; Mägiste 1976). Käskiva kõneviisi minevikku väljendab nud-vorm, nt Öelnud siis kohe, et nii ei saa!, Paras sulle. Ostnud siis varem ära! Et nud-vorm on grammatilise tähenduse poolest väga mitmene - ta on kasutusel nii isikulise tegumoe mineviku kesksõnana, liitvormi osana kindla kõneviisi eituses kui ka mitmesõnalistes minevikuvormides -, siis talle veel ühe võimaliku grammatilise tähenduse omistamine vajab tõsist põhjendamist. Seda, et vormil on lisaks teadaolevatele veel üks tähendus, võiks ju käsitleda kui mõne olemasoleva spetsiifilist kasutusjuhtu. Siin tulebki mängu ärnud kui sõnavorm, millel pole ühtegi muud tõlgendusvõimalust peale käskiva kõneviisi mineviku: fakt, et selline sõnavorm on kasutusel, viitab sellele, et talle vastav grammatiliste kategooriate väärtuste kombinatsioon - käskiva kõneviisi minevik - on keelekasutajate teadvuses tõepoolest olemas; ja nagu juba öeldud, pole olemas eitava kõne vormi, ilma et oleks olemas ka vastav (st muude tunnuste osas sama spetsiifiline) jaatava kõne vorm.

Infiniitsed vormid erinevad üksteisest muuhulgas selle poolest, kas neis on esindatud verbile omased grammatilised kategooriad tegumood ja aeg. Infiniitsete vormide tabel ei ole sama sümmeetriline kui finiitsete oma, kuid tunnuste järjekord on sama mis finiitsetel vormidelgi. 
Infiniitsed lihtvormid

\begin{tabular}{|c|c|c|c|c|}
\hline tegumood & \multicolumn{3}{|l|}{ aeg } & näide \\
\hline \multirow[t]{8}{*}{ isikuline } & olevik & \multirow{2}{*}{\multicolumn{2}{|c|}{ kesksõna }} & elav \\
\hline & minevik & & & elanud (4) \\
\hline & \multicolumn{4}{|c|}{ aja kategooriata vormid } \\
\hline & $m a$-tegevusnimi & \multirow[t]{5}{*}{ kääne } & sisseütlev & elama \\
\hline & & & seesütlev & elamas \\
\hline & & & seestütlev & elamast \\
\hline & & & saav & elamaks \\
\hline & & & ilmaütlev & elamata \\
\hline \multirow[t]{4}{*}{ umbisikuline } & olevik & \multirow{2}{*}{\multicolumn{2}{|c|}{ kesksõna }} & elatav \\
\hline & minevik & & & elatud (6) \\
\hline & \multicolumn{4}{|c|}{ aja kategooriata vormid } \\
\hline & $m a$-tegevusnimi & kääne & sisseütlev & elatama \\
\hline \multicolumn{5}{|c|}{ tegumoe kategooriata vormid } \\
\hline \multicolumn{4}{|l|}{$d a$-tegevusnimi } & elada \\
\hline \multicolumn{4}{|l|}{ des-vorm } & elades \\
\hline
\end{tabular}

\section{5. $k s e$-lõpulised vormid: uus probleem}

Vahel juhtub, et keelekasutaja loob grammatikatajuga kooskõlas oleva sõnavormi, mida siiski ei õnnestu meie väidetavalt kõiki võimalikke kombinatsioone hõlmavasse tabelisse paigutada. Selliste vormide olemasolu on tähtis, sest viitab lünkadele olemasolevas keelekirjelduses.

On teada, et eesti keeles on kolm leksikaliseerunud verbivormi - kuulukse, tunnukse ja näikse -, mida ei õnnestu paradigmasse paigutada; tegelikus keelekasutuses võib kohata ka neile sarnaseid vorme kuuldukse ja tundukse. Üllatuslikult selgub keelekasutusest, et on olemas ka üksikud minevikuvormid, nt kuulunukse, näinukse, olnukse:

Olnukse kuulda, et Edelaraudtee ja Elektriraudtee vahel pole enam kokkulepet (Facebook)

nagu tänastest uudistest kuulunukse (naistekas.delfi.ee)

Urises sulane, mis ta urises, kuid lõpuks pidi ometi koera keelama ja juhatama meid trepist üles elumajja, kus näinukse mingit pidu peetavat. (Ruben 2001)

Seega on vorme juba nii palju, et võiks naljaga pooleks proovida neile ka paradigmatabelis kohta leida. Et umbisikulise tegumoe tunnus puudub, on tegu isikulise tegumoe vormidega; pöörde ja eituse-jaatuse suhtes on need vormid kindlasti spetsifitseerimata. Küsitavaks jääb veel kõneviisi küsimus: kuna ükski juba kasutusel olevatest ei näikse sobivat, siis võiks tulla kõne alla mõni kahtlust ja ebakindlust väljendav kõneviis, nt kahtlev ehk dubitatiiv. 
Tõsisema probleemi tõstatab antud juhul aga $k s e$-lõpuliste, kuid seejuures minevikuliste vormide olemasolu. Tunnust $k s e$ peetakse keeleajalooliseks oleviku tunnuseks, kusjuures sama tunnus esineb regulaarselt ka umbisikulise tegumoe kindla kõneviisi oleviku jaatusvormis (elatakse) (EKG: 238). Samal ajal ei ole võimalik, et ühes ja samas vormis on korraga nii mineviku tunnus ( $n u$ ) kui ka oleviku tunnus ( $k s e$ ), millest omakorda järeldub, et kse ei saa antud vormides olla oleviku tunnuseks. See jällegi näib tähendavat, et ka umbisikulise tegumoe vormi (nt elatakse) puhul ei saa tüvele lisanduvat osa tõlgendada kui $t a+k s e$, st kui aglutinatiivselt liituvaid umbisikulise tegumoe ja oleviku tunnuseid, vaid tuleb teda tõlgendada kui umbisikulise tegumoe tunnuse jagamatut allomorfi takse. See tõlgendus on kooskõlas EKG-ga (EKG: 243), kuid tuleb nõustuda Hannu Remese kriitikaga (2009: 130), et sel moel suurendatakse kunstlikult allomorfide hulka. Head lahendust siin ei paistagi.

\section{Lõpetuseks}

Grammatilised kategooriad esinevad verbi sõnavormides komplektidena, mis moodustavad üsna korrapärase süsteemi, mis avaldub sõnavormide aglutinatiivse ülesehitusena. Seda korrapära on ka silmaga näha, kui sõnavormide paigutamisel paradigmatabelisse järgida tunnusmorfeemide sõnasisest järjestust. Muu hulgas hakkab silma, et paradigmas peaaegu pole auke ja et alaspetsifitseeritus ehk kategooria väärtuste määramatus puudutab just neid kategooriaid, mille tunnusmorfeemid asuvad sõnavormi äärtes: sõnast eespool (eitus, mida esindab eitussõna ei või ära) või sõna lõpus (pööre ehk isik ja arv).

Kui vaadata tuntud asjadele uuest küljest, siis võivad ilmneda seaduspärasused, mis jäid varem varjatuks. Sama lugu on ka eesti verbi kategooriatega. Kui loobuda katsest kõiki finiitseid vorme seostada pöördekategooriaga, hakkab silma, et mõned finiitsed vormid tõepoolest ei olegi pöördekategooria suhtes määratletud. Alaspetsifitseeritus kehtib ka GU-lõpulise käskiva kõneviisi vormi kohta, ja see omakorda võimaldab esitada käskiva kõneviisi vormide tõlgenduse ilma möönvat kõneviisi - millel nagunii puudub eristav morfoloogiline tunnus - postuleerimata.

Esitletud lihtvormide paradigmas väljenduvaid kategooriate kombinatsioone on edaspidi kavas kasutada ka tekstikorpuste automaatsel märgendamisel.

Artikli valmimist on toetanud Haridus- ja Teadusministeeriumi uurimistoetus IUT20-56 „Eesti keele arvutimudelid” ning Norra ja Euroopa Majanduspiirkonna finantsmehhanismide teaduskoostöötoetus EMP160 „Saami-Eesti keeletehnoloogiaalane koostöö: sarnased keeled, ühesugune tehnoloogia”. 


\section{Tekstinäidete allikad}

Facebook. https:/et-ee.facebook.com/EdelasuunalineRaudtee/posts/395145587267 067

K r i k m a n n, Arvo, Ütluste semantikast. http://www.folklore.ee/ kriku/RETSEM. naistekas.delfi.ee. http://naistekas.delfi.ee/foorum/read.php?10,1563253

R u b e n, Aarne 2001. Volta annab kaeblikku vilet. Tallinn: Tänapäev.

\section{Kirjandus}

B y b e e, Joan L. 1985. Morphology. A Study of the Relation between Meaning and Form. Amsterdam-Philadelphia: John Benjamins.

EKG = Mati Erelt, Reet Kasik, Helle Metslang, Henno Rajandi, Kristiina Ross, Henn Saari, Kaja Tael, Silvi Vare, Eesti keele grammatika I. Morfoloogia. Sõnamoodustus. Tallinn: Eesti Teaduste Akadeemia Eesti Keele Instituut, 1995.

EKK = Mati Erelt, Tiiu Erelt, Kristiina Ross, Eesti keele käsiraamat. Kolmas, täiendatud tr. Tallinn: Eesti Keele Sihtasutus, 2007.

Erelt, Mati 2002. Does Estonian have the jussive? - Linguistica Uralica, kd XXXVIII, nr 2, lk 110-117.

E r e lt, Mati 2013a. Keeldkõne vormidest. - Emakeele Seltsi aastaraamat, nr 58. Tallinn: Teaduste Akadeemia Kirjastus, lk 30-38.

E r elt, Mati 2013b. Eesti keele lauseõpetus. Sissejuhatus. Öeldis. Tartu: Tartu Ülikooli eesti keele osakond.

Erelt, Mati, Metslang, Helle 2004. Grammar and pragmatics: Changes in the paradigm of the Estonian imperative. - Linguistica Uralica, $\mathrm{kd}$ XLV, $\mathrm{nr} 3$, lk 161-178.

G r e e n b e r g, Joseph H. 1990. Some universals of grammar with particular reference to the order of meaningful elements. - On Language. Selected Writings of Joseph H. Greenberg. Toim Keith Denning, Suzanne Kemmer. Stanford: Stanford University Press, lk 40-70.

Hint, Mati 1969. Eesti grammatikakirjanduse põhimõttelised ja konkreetsed probleemid. Uute eesti keele grammatikate puhul. - Keel ja Kirjandus, nr 6, lk 327-341.

Met s l a n g, Helle, S e p p e r, Maria-Maren 2010. Mood in Estonian. - Mood in the Languages of Europe. (Studies in Language Companion Series 120.) Toim Björn Rothstein, Rolf Thieroff. Amsterdam-Philadelphia: John Benjamins, lk 528-550.

M ä g i s t e, Julius 1976. Viron imperatiivin preteriti. - Virittäjä, kd 80, nr 1, lk 48-51.

P e n j a m, Pille 2005. Jussiivi kasutusest eesti vanemas kirjakeeles. - Emakeele Seltsi aastaraamat, nr 50. Tallinn: Teaduste Akadeemia Kirjastus, lk 68-92.

R e m e s, Hannu 2009. Muodot kontrastissa. Suomen ja viron vertailevaa taivutusmorfologiaa. (Acta Universitatis Ouluensis B Humaniora 90.) Oulu: Oulun yliopisto.

S a a r e s t e, Andres 1952. Kaunis emakeel I. Lund: Eesti Kirjanike Kooperatiiv.

Sivers, Fanny de 1969. Analyse grammaticale de l'estonien parlé. ClermontFerrand. 
Viits o, Tiit-Rein 1976. Eesti muutkondade süsteemist. - Keel ja Kirjandus, nr 3, lk 148-162.

Viks, Ülle 1984. Sõnavormide homonüümia eesti keeles. - Keel ja Kirjandus, nr 2, lk 97-105.

Viks, Ülle 1992. Väike vormisõnastik. 1, Sissejuhatus ja grammatika. Tallinn: Eesti Teaduste Akadeemia.

\section{Estonian verb paradigm}

Keywords: Estonian, verb, morphological categories

The article deals with the problem how to represent the morphological composition of the paradigmatic simple forms of the Estonian verb with a view to good theoretical justification and practical suitability for computer and corpus linguistics. The major issue here is systematic homonymy and underspecification. The article discusses the possible influence of paradigmatic representation on the understanding of the system of categories, comments on the imperative and jussive moods, makes an original suggestion of how to place certain morphological forms in the paradigmatic table, and points out some forms ending in -kse, which do not fit in the traditional framework.

The article argues that there are some finite verb forms in the Estonian verb paradigm that are not specified as to the category of conjugation. Underspecification also applies to the imperative form ending in -gu, which is a fact enabling an explanation of the semantic heterogeneity of the imperative forms as well as an interpretation of those forms without postulating the jussive mood despite the absence of a distinctive morphological marker.

In word forms, the morphological categories of Estonian simple verbs are manifested as assemblies, which belong to a rather regular system and function as building blocks in the structure of agglutinative word forms. This regularity is visible to an observant eye when following the intra-word order of the marker morphemes. Note that the paradigm is almost gapless, while underspecification applies to those categories whose marker morphemes are positioned at word edge, either preceding the verb (like negation words ei or ära) or word-finally (personal ending). Even some forms traditionally not included in the simple verb paradigm, such as the past imperative or the forms ärnud and ärdagu of the negation word ära, fit well in a paradigm based on grouped marker morphemes.

Heiki-Jaan Kaalep (b. 1962), PhD, University of Tartu, Senior Researcher, Heiki-Jaan.Kaalep@ut.ee 